\title{
Leukemia Limfositik Kronik pada Limfoma Non Hodgkin
}

\author{
Rahmi Sahreni ${ }^{1}$, Irza Wahid ${ }^{2}$
}

\begin{abstract}
Abstrak
Leukemia Limfositik Kronik (LLK) adalah suatu keganasan hematologik yang ditandai oleh proliferasi klonal dan penumpukan limfosit B neoplastik dalam darah. Limfoma Non Hodgkin (LNH) adalah kelompok keganasan primer limfosit B, limfosit $T$ jarang berasal dari sel NK (natural killer). Keduanya merupakan keganasan hematologi yang berasal dari limfosit B. Transformasi LNH menjadi LLK sangat jarang terjadi. Dilaporkan perempuan 38 tahun dengan keluhan utama benjolan di leher muncul kembali sejak 1 bulan yang lalu setelah kemoterapi LNH dengan regimen Cyclophosfamide, Doxorubicine, Vincristine dan prednison selama 6 siklus. Pucat sejak 2 tahun yang lalu dan dialkukan BMP dengan kesan normal. Pemeriksaan fisik didapatkan konjungtiva anemis, pembesaran kelenjar getah bening di regio colli dan inguinal, hepatosplenomegali. Didapatkan $\mathrm{Hb}$ 8,8 gr/dl, leukosit 40.900/mm3 gambaran darah tepi leukosit jumlah meningkat, limfositosis, flower cells. Hasil BMP didapatkan infiltrasi sel seri limfopoeitik didominasi limfosit (77\%), limfoblast (6\%), smudge cells sesuai gambaran LLK. Patologi Anatomi sesuai LNH. Imunofenotyping CD 20 positif. USG Abdomen didapatkan hepatosplenomegali dan limfadenopati multipel paraaorta. Regimen Kemoterapi diberikan Rituximab, Fludarabine, Cyclophosphamide dan menghasilkan remisi komplit.
\end{abstract}

Kata kunci: limfoma non hodgkin, leukemia limfositik kronik, transformasi

\begin{abstract}
Chronic lymphositic leukemia (CLL) is one of haematology malignancies where characterized by clonal proliferation and neoplastic $B$ lymphocyte in blood. Non hodgkin lymphoma (NHL) is primary malignancy group $B$ lymphocyte, $T$ lymphocyte and natural killer cell. Both of them are haematology malignancies that originated by $B$ lymphocyte.LNH transformation become CLL is rare. Reported a case a 38 years old female patient with chief complain is lumb on the neck relaps since 1 month ago after LNH chemotherapy with Cyclophosfamide, Doxorubicine, Vincristine and prednisone for 6 cycles. Pale since 2 years ago and BMP was done that the result was normal. From physical examination anemic conjungtiva, enlarge lymphe node at regio neck and inguinal, hepatosplenomegaly. From laboratory result $\mathrm{Hb}$ 8,8 gr/dl, Leucocyte 40.900/mm3, blood perifer swab increase leucocyte count, lymphocytosis, flower cells. From BMP was dominated infiltration of lymphopoeitic series that lymphocyte (77\%), lymphoblast (6\%), smudge cell were suitable with chronic lymphocitic leukemia. From histopatology was suitable with NHL. Imunophenotyping CD 20 positive. Abdominal USG hepatosplenomegaly and multiple paraaorta lymphadenophaty. Chemotherapy regimen was given Rituximab, Fludarabine, Cyclophosphamide and reach complete remission.
\end{abstract}

Keywords: non hodgkin lymphoma, chronic lymphocitic leukemia, transformation

Affiliasi penulis: 1. Program Pendidikan Dokter Spesialis-1 IImu Penyakit Dalam FK Unand 2. Subbagian Hematologi dan Onkologi Medis Bagian IImu Penyakit Dalam FK Unand/RSUP M Djamil Padang Korespondensi: pibipd@yahoo.comTelp: 0751-37771

\section{PENDAHULUAN}

Leukemia Limfositik Kronik (LLK) adalah suatu keganasan hematologik yang ditandai oleh proliferasi klonal dan penumpukan limfosit B neoplastik dalam darah. ${ }^{1,2}$ Penyebab LLK belum diketahui, ada kemungkinan yang berperan adalah abnormalitas kromosom, onkogen dan retrovirus (RNA tumour virus). ${ }^{1}$ Usia rerata pasien saat didiagnosis berusia 65 tahun, hanya $10-15 \%$ kurang dari 50 tahun. Angka kejadian di negara barat 3/100.000. Pada populasi geriatri, insiden di atas usia 70 tahun sekitar 50/100.000. Risiko terjadinya LLK meningkat seiring 
usia. Perbandingan risiko relatif pada pria tua adalah 2,8:1 perempuan tua. Kebanyakan pasien memiliki ras kaukasia dan berpendapatan menengah. ${ }^{1}$ Pada awal diagnosis, kebanyakan pasien LLK tidak menimbulkan gejala,. Pada pasien dengan gejala, paling sering ditemukan limfadenopati generalisata, penurunan berat badan dan kelelahan. Gejala lain meliputi hilangnya nafsu makan dan penurunan kemampuan latihan/olahraga. Demam, keringat malam dan infeksi jarang terjadi pada awalnya, tetapi semakin mencolok sejalan dengan perjalanan penyakitnya. Akibat penumpukan sel B neoplastik, pasien yang asimptomatik pada saat diagnosis pada akhirnya akan mengalami limfadenopati, splenomegali dan hepato megali. ${ }^{1}$ Gambaran laboratorium ditemukan adanya limfositosis, anemia normositik normokrom terdapat pada stadium lanjut akibat infiltrasi sumsum tulang atau hipersplenisme.Trombositopenia terjadi pada banyak pasien. Pada aspirasi sumsum tulang menunjukkan adanya penggantian elemen sumsum tulang oleh limfosit. 1,3

Limfoma Non Hodgkin (LNH) juga merupakan kelompok keganasan prirner limfosit yang didominasi berasal dari limfosit $B$ yang berada dalam sistem limfe. Insiden penyakit ini khususnya $\mathrm{LNH}$ terlihat terus mengalami peningkatan sekitar $3,4 \%$ setiap tahunnya. The American Cancer Society dalam Roty (2014) memperkirakan terdapat 65.980 kasus baru setiap tahun dan 19.500 di antaranya meninggal dunia akibat LNH pada tahun 2009. ${ }^{1}$

\section{KASUS}

Seorang pasien perempuan usia 38 tahun dirawat di bangsal Penyakit Dalam RSUP M Djamil Padang dengan keluhan utama benjolan di leher sejak 1 bulan sebelum masuk rumah sakit. Awalnya benjolan muncul pada telinga 2 tahun yang lalu. Benjolan sebesar biji jagung makin lama makin membesar sebesar kelereng, tidak disertai rasa nyeri dan warna kemerahan. Pasien sudah menjalani pemeriksaan jaringan dan dinyatakan menderita keganasan kelenjar getah bening dan telah menjalani kemoterapi sebanyak enam siklus di RSUD Bukittinggi dimana kemoterapi terakhir pada bulan Agustus 2013 dan benjolan pun menghilang, tetapi satu bulan ini benjolan muncul kembali pada leher kiri dan kanan, benjolan awalnya sebesar biji jagung kemudian makin lama makin membesar sebesar kelereng. Benjolan juga muncul di lipat paha kiri dan kanan pasien dan juga tidak disertai rasa nyeri dan warna kemerahan. Pucat sejak 2 tahun yang lalu, pucat baru disadari pasien saat hamil anak ketiga. Pucat disertai pusing dan badan letih, sehingga pasien tidak dapat melakukan aktivitas berat lagi. Perdarahan dari hidung, gusi dan kulit tidak ada. Muntah darah dan BAB hitam tidak ada. Demam tidak ada. Batuk lama tidak ada. Nyeri menelan tidak ada. Keringat malam tidak ada. Penurunan berat badan tidak ada. BAK tidak ada keluhan. Pasien kembali berobat ke RSUD Bukittinggi dan menjalani pemeriksaan darah dan didapatkan sel darah putih pasien sangat meningkat dan dianjurkan dirujuk ke hematologist RSUP Dr. M Djamil untuk penelusuran lebih lanjut. Pada pemeriksaan fisik didapatkan konjungtiva anemis, pada kelenjar getah bening terdapat pada multipel limfadenopati pada regio colli dextra dan sinistra serta pada regio inguinal dextra dan sinistra. Terdapat hepatosplenomegali. Pada pemeriksaan laboratorium didapatkan hemoglobin $8,8 \mathrm{gr} / \mathrm{dl}$, leukosit 40.900/mm3, hematokrit $27 \%$, trombosit $140.000 / \mathrm{mm} 3$, diffcount 0/4/0/4/92/0, LED $19 \mathrm{~mm} / \mathrm{jam}$ dan pada gambaran darah tepi didapatkan Eritrosit Anisositosis normokrom, Leukosit jumlah meningkat dengan limfositosis, Trombosit Jumlah kurang, morfologi dalam batas normal

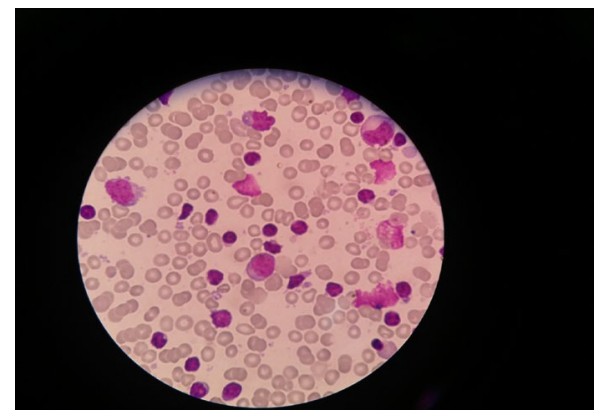

Gambar 1. Gambaran darah tepi 


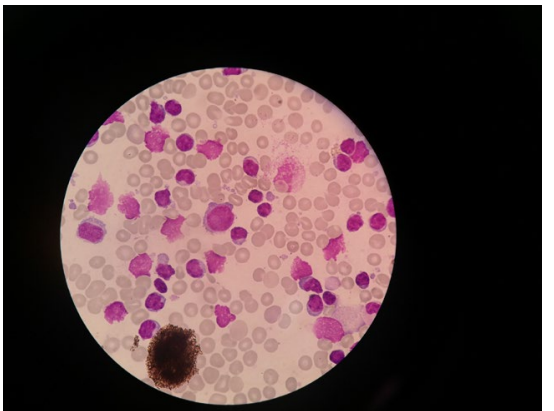

Gambar 2. Hasil BMP

Kesan: Partikel ditemukan, selularitas hiperselular, megakariosit sukar ditemukan. Aktivitas eritropoeitik, granulopoeitik dan trombopoeitik tertekan. Ditemukan infiltrasi sel-sel seri limfopoeitik dengan dominasi limfosit (77\%), limfoblast (6\%). Banyak ditemukan smudge cells. Kesimpulan : Sesuai dengan Leukemia Limfositik Kronik daan dilakukan biopsi dengan kesan Limfoma Maligna Non Hodgkin, tipe sel kecilmenengah, difus dengan hasil pemeriksaan Imunohistokimia CD 20 positif.
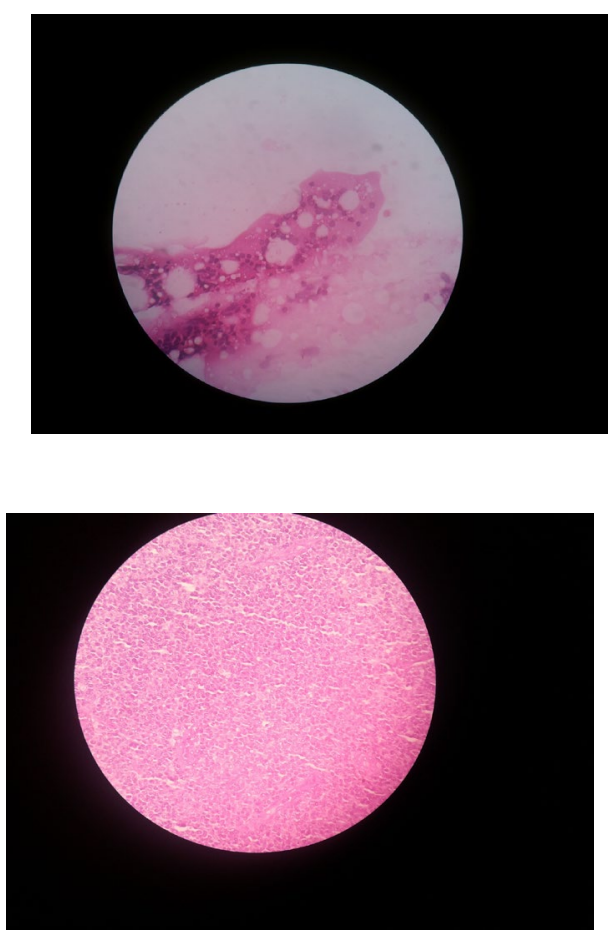

Gambar 3. Gambaran histopatologi Hasil USG Abdomen

Kesan: Hepatosplenomegali dan limfadenopati multiple paraaorta ec Limfoma

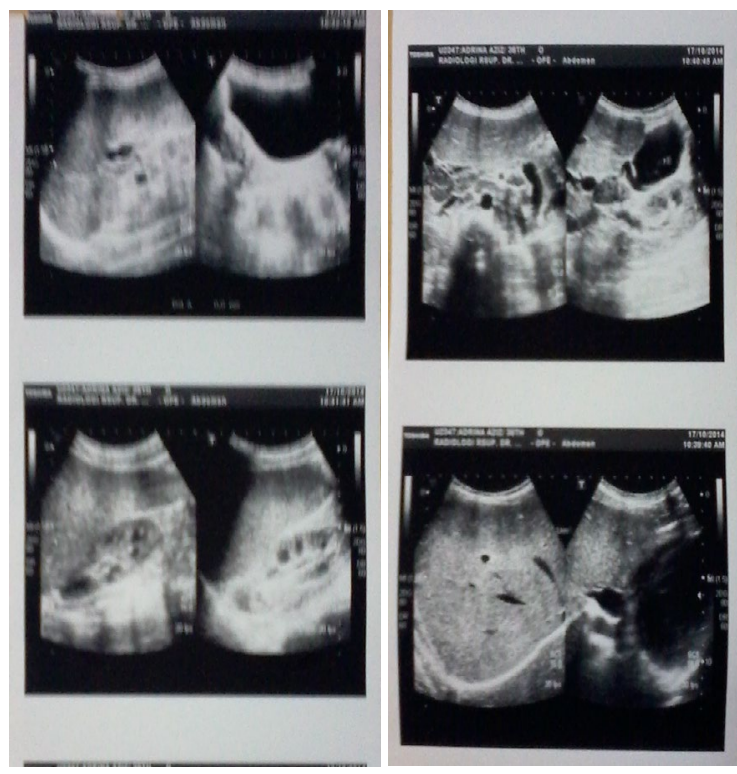

Gambar 4. Gambaran USG abdomen

\section{PEMBAHASAN}

Telah dirawat pasien perempuan usia 38 tahun dengan diagnosis akhir Limfoma Maligna Non Hodgkin Relaps tipe sel kecil-menengah difus stadium IV skala karnofsky 90 dan Leukemia Limfositik Kronik. Pada pasien ini didiagnosis sebagai Limfoma Maligna Non Hodgkin Relaps tipe sel kecil-menengah difus stadium IV ditegakkan berdasarkan anamnesis dimana didapatkan keluhan benjolan pada leher dan lipat paha kiri dan kanan. Riwayat keganasan kelenjar getah bening yang telah menjalani kemoterapi sebelumnya. Pada pemeriksaan fisik didapatkan konjungtiva anemis, pembesaran kelenjar getah bening pada regio colli dextra dan sinistra serta pada regio inguinal dextra dan sinistra, konsistensi kenyal tanpa disertai tanda-tanda radang. Sebagian besar pasien datang dengan keluhan pembesaran kelenjar getah bening yang tidak nyeri satu atau lebih regio kelenjar getah bening perifer. ${ }^{1}$ Pada pemeriksaan abdomen didapatkan hepatomegali dan splenomegali. Dari pemeriksaan laboratorium didapatkan anemia, leukositosis dan limfositosis. Disamping itu pemeriksaan yang merupakan gold standar untuk menegakkan diagnosis yaitu biopsi dimana hasilnya adalah Limfoma Maligna Non Hodgkin, tipe sel kecilmenengah, difus. Berdasarkan Kesepakatan Ann Arbor, stadium penyakit pasien ini adalah stadium IV 
dimana stadium IV yaitu jika mengenai 1 organ ektralimfatik atau lebih secara difus serta keterlibatan kelenjar getah bening jauh. ${ }^{1}$ Pada USG abdomen juga dinyatakan telah terjadi pembesaran kelenjar multiple paraaorta. Pada pasien ini sudah terjadi keterlibatan organ ekstralimfatik yaitu hepar dan lien serta juga telah melibatkan sum sum tulang dimana didapatkan netropenia dan trombositopenia. Pada pasien terbukti pada hitung jenis terdapat penurunan jumlah netrofil batang ataupun segmen serta penurunan jumlah trombosit. Bukti lain keterlibatan sum sum tulang yaitu pasien juga didiagnosis sebagai leukemia limfositik kronik. Status performa pada pasien ini berdasarkan skala karnosky yaitu 90 dimana mampu beraktivitas secara normal dengan tanda penyakit yang minimal.

Pasien ini juga didiagnosis sebagai leukemia limfositik kronik. Secara klinis pasien tidak menunjukkan gejala tetapi manifestasi klinis yang paling sering adalah limfadenopati, splenomegali dan hepatomegali. Sekitar $20-30 \%$ pasien tidak menunjukkan kelainan fisik. Kelainan yang paling sering dijumpai adalah limfadenopati. Sekitar 50\% pasien mengalami limfadenopati dan atau hepatosplenomegali. Pada pemeriksaan laboratorium didapatkan leukositosis dengan hitung jenis terdapat limfositosis. Diagnosis pasti leukemia limfositik kronik pada pasien ini adalah BMP. Hasil BMP didapatkan Ditemukan infiltrasi sel-sel seri limfopoeitik dengan dominasi limfosit (77\%), limfoblast (6\%) dan banyak ditemukan smudge cells. Ini sesuai dengan literatur dimana tanda patognomonik Leukemia Limfositik Kronik adalah peningkatan jumlah leukosit dengan limfositosis. 1

Penatalaksanaan pada pasien ini sangat bergantung pada stadium dan indeks prognostik. Berdasarkan Indeks Prognostik pasien LNH, pasien ini tergolong high risk dengan skor total 5 yang terdiri dari umur $<60$ tahun(1), Tumor stage Annarbor stadium IV (1), LDH serum meningkat (1), ECOG performance status (1) dan keterlibatan ekstranodal >1 tempat (1). ${ }^{3}$ Penatalaksanaan pada pasien ini adalah diberikan kemoterapi kombinasi cyclofosfamid dan analog purin yaitu fludarabin kombinasi dengan Rituximab sebagai terapi target anti CD 20. Fludarabin merupakan obat yang efektif untuk pengobatan leukemia limfositik kronik dan limfoma. ${ }^{4,5}$ Peneltian terbaru dengan terapi berbasis fludarabin pada LLK yang sebelumnya tidak diterapi menunjukkan hasil yang menggembirakan. Pasien LLK yang sebelumnya tidak diterapi diberikan rituximab untuk menunjang fludarabin dan cyclofosfamid selama 6 siklus. Laporan awal dari 134 pasien yang mendapat pengobatan komplit, 66\% mencapai respon komplit dan secara keseluruhan dijumpai rasio respon 95\%.6,7 Pada pasien ini tidak diberikan radioterapi. Radioterapi hanya bersifat paliatif dapat berupa radiasi limpa untuk penurunan ukuran limpa dan jika terdapat lesi-lesi yang besar (bulky nodal masses).2

\section{SIMPULAN}

Transformasi LNH menjadi LLK sangat jarang terjadi. Penatalaksanaan kedua keganasan hematologi ini respon terhadap kemoterapi.

\section{DAFTAR PUSTAKA}

1. Roty L. Leukemia limfositik kronik. Dalam: Setiadi S, Alwi I, Sudoyo A, Simadibrata M, Syam $A F$,editor (penyunting). Buku ajar ilmu penyakit dalam. Edisi ke-6. Jakarta: Interna Publishing; 2014.hlm.2693-99.

2. Harrison I, Randolph T. Harrison's manual medicine. USA: Mc Graw Hill.2013.hlm.414-16.

3. Setioyohadi, B. Limfoma Non Hodgkin. Dalam: Setiadi S, Alwi I, Sudoyo A, Simadibrata M, Syam $A F$, editor (penyunting). Buku ajar ilmu penyakit dalam. Edisi ke-6. Jakarta: Interna Publishing; 2014.hlm.1251-60.

4. Wendtner CM, Gregor M. Current perspectives on the role of chemotherapy in chronic lymphocytic leukemia. Leukemia\& Lymphoma. 2018;300-10.

5. Robak T, Robak P, Lech Maranda E. Rituximab plus fludarabine and cyclophosphamide or other agents in chronic lymphocytic leukemia. Expert Rev Anticancer Ther. 2010;10(10):1529-43.

6. Montillo. Fludarabine in the treatment of chronic lymphocytic leukemia: a review. Ther Clin Risk Manag. 2009;5:187-207. 
7. Rosta A, Robak T, Maurer J,Valente N,Wenger MK,Montillo $\mathrm{M}$, et al. Rituximab plus fludarabine and cyclophosphamide prolongs progression-free survival compared with fludarabine and cyclophosphamide alone in previously treated chronic lymphocytic leukemia. J Clin Oncol. 2010; 28(10): 1756-65. 